\title{
3D models related to the publication: The late middle Miocene Mae Moh Basin of northern Thailand: the richest Neogene assemblage of Carnivora from Southeast Asia and a paleobiogeographic analysis of Miocene Asian carnivorans
}

\author{
Grohé Camille $^{1 *}$, de Bonis Louis ${ }^{1}$, Chaimanee Yaowalak ${ }^{1}$, Surault Jérôme ${ }^{1}$, Jaeger Jean-Jacques ${ }^{1}$ \\ ${ }^{1}$ Palevoprim UMR 7262, CNRS, Université de Poitiers, France \\ *Corresponding author: camille.grohe@univ-poitiers.fr
}

\begin{abstract}
The present 3D Dataset contains the 3D models described and figured in the following publication: Grohé et al. 2020, the late middle Miocene Mae Moh Basin of northern Thailand: the richest Neogene assemblage of Carnivora from Southeast Asia and a paleobiogeographic analysis of Miocene Asian carnivorans. American Museum Novitates. http://digitallibrary.amnh.org/handle/2246/7223
\end{abstract}

Keywords: Carnivora, Mustelidae, otters, skull, upper teeth

Submitted:2020-02-06, published online:2020-06-03. https://doi.org/10.18563/journal.m3.109

\section{INTRODUCTION}

In this paper, we present 3D models of specimens of two fossil otters from the middle Miocene Mae Moh Basin, northern Thailand: two skulls and one model of upper teeth reconstructed from one of the skulls. Otter remains are generally scarce in the fossil record, mostly comprising fragmentary jaws and isolated teeth. The two skulls were found in the Na Khaem Formation of the Mae Moh Basin (Grohé et al. 2020), in the lignite zones K and J, dated by magnetostratigraphy to 13.4-13.2 and 12.8-12.2 Ma, respectively (Benammi et al., 2002; Coster et al., 2010). They are both flattened dorsoventrally and went through various taphonomic deformations. Siamogale bounosa is a new species and it is the second species of Siamogale recovered from the Mae Moh Basin (Fig. 1 A-B and table 1). The oldest Thai $S$. thailandica was initially described by a lower carnassial (Ginsburg et al., 1983), then by over a hundred of fragmentary jaws and isolated teeth (Grohé et al., 2010). The third species of Siamogale, from latest Miocene deposits of the Zaotong Basin, Yunnan Province of China, and from the early Pliocene of the Yushe Basin, Shanxi Province of China, is a wolf-sized otter (Wang et al., 2018), which shows more derived morphological features compared to the Mae Moh species. Siamogale belongs to a south and eastern Asian clade of bunodont otters (Wang et al., 2018), for which the teeth and the mandibular apparatus are specialized for crushing hard and/or abrasive food items (Tseng et al., 2017). Vishnuonyx maemohensis is a new species of Vishnuonyx, a genus previously recorded mostly by upper teeth from the Siwaliks and Eastern Africa (Pilgrim, 1932; Werdelin, 2003). We described the most complete specimen of Vishnuonyx ever found (Fig. 2 A-E and table 1) and suggested that the genus is closely related to Torolutra, a late Miocene to Pleistocene otter from northern and eastern Africa.

$\begin{array}{ccc}\text { Model ID } & \text { Taxon } & \text { Description } \\ \text { M3\#505 } & \text { Siamogale } & \text { Cranium } \\ \text { (MM-54) } & \text { bounosa } & \\ \text { M3\#506 } & \text { Vishnuonyx } & \text { Cranium } \\ \text { (MM-78) } & \text { maemohensis } & \\ \text { M3\#507 } & \text { Vishnuonyx } & \text { Upper teeth } \\ \text { (MM-78) } & \text { maemohensis } & \end{array}$

Table 1. List of models. MM: Mae Moh fossils. The specimens are provisionally stored at the University of Poitiers.

\section{METHODS}

The 3D surfaces were extracted semi-automatically with Avizo Lite 9.5 (Visual Data Analysis, Zuse Institute Berlin and Thermo Fisher Scientific, USA), using the segmentation threshold selection tool, and further processed using Geomagic Studio (Geomagic Inc., USA). We also used Geomagic Studio to stitch the broken teeth of MM-78 back together and to position them to approximate the dental arch shape of an otter based on a skull of Lutra lutra. The 3D surface models are provided in .ply format and therefore can be opened with a wide range of freeware. Additionally, each surface was oriented in ISE-MeshTools (Lebrun, 2014).

\section{ACKNOWLEDGEMENTS}

We are grateful to Arnaud Mazurier from the University of Poitiers for acquiring the scans of the skulls of the fossil otters. We thank the PALEVOPRIM laboratory for funding.

\section{BIBLIOGRAPHY}

Benammi M., Benammi M., Urrutia-Fucugauchia J., Alva-Valdiviaa L.M., Chaimanee Y., Triamwichanon S. and Jaeger J.-J., 2002. 

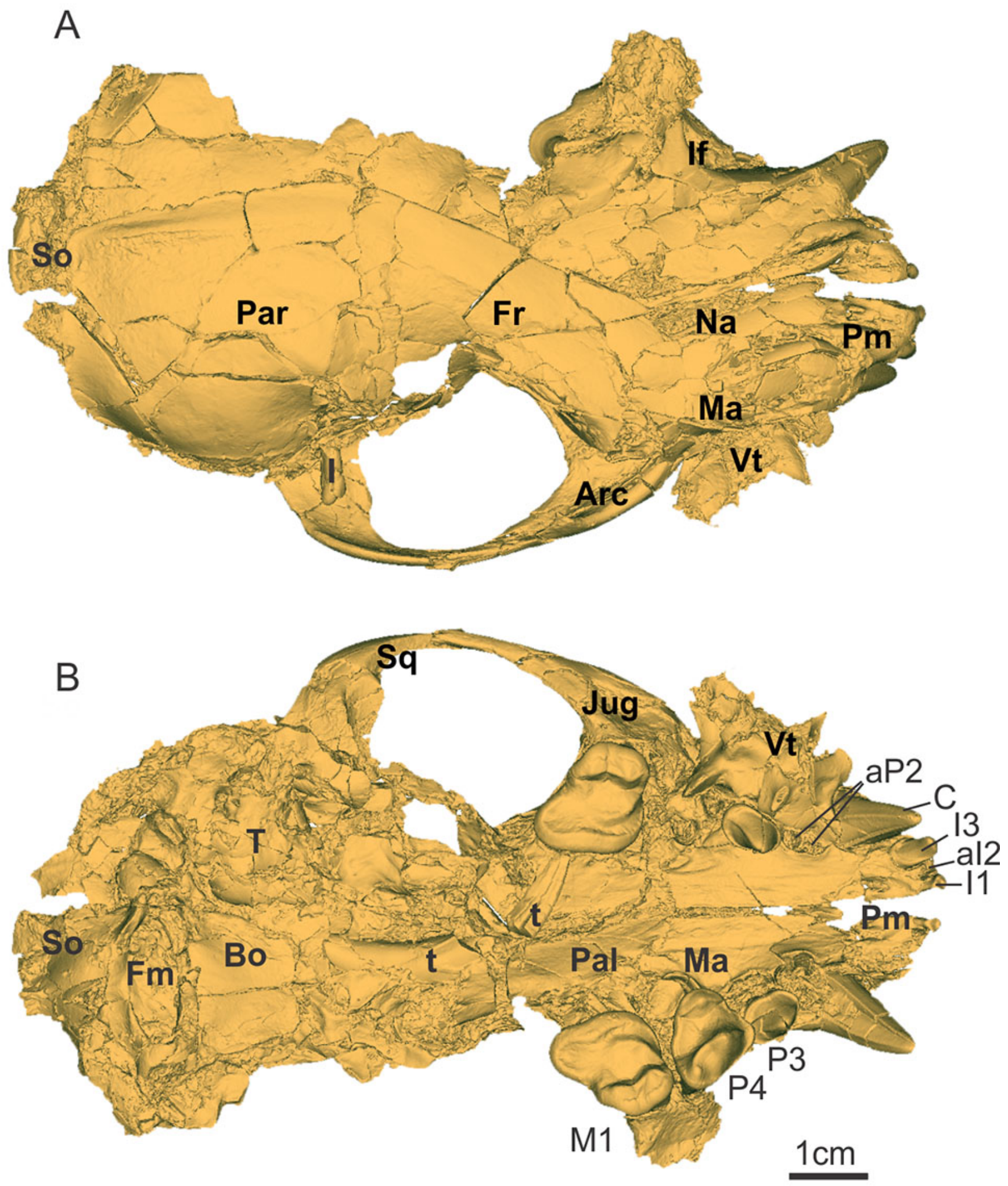

Figure 1. Siamogale bounosa. virtual reconstruction of the holotype skull MM-54, in dorsal (A) and ventral views (B). Abbreviations: a, alveolus/alveoli; Arc, zygomatic arch; Bo, basioccipital; Fm, foramen magnum; Fr, frontal; I, upper incisor; If, infraorbital foramen; Jug, jugal; M, upper molar; Ma, maxilla; Na, nasal; P, upper premolar; Pal, palatine; Par, parietal; Pm, premaxilla; So, supraoccipital; Sq, squamosal; T, tympanic bulla; $\mathbf{t}$, indeterminate tooth (probably belonging to a different species); $\mathbf{V t}$, cervical vertebra. 


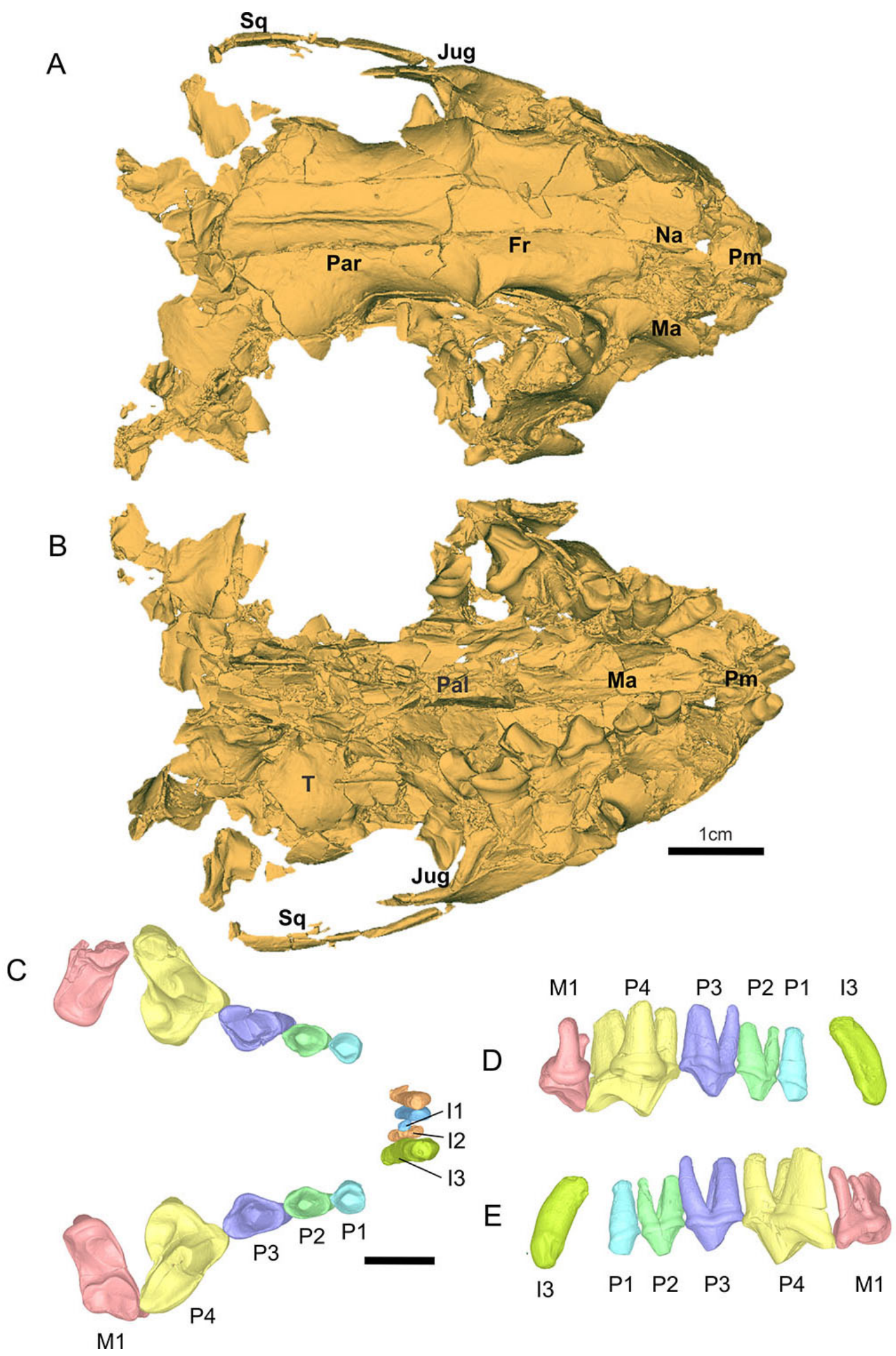

Figure 2. Vishnuonyx maemohensis, virtual reconstruction of the skull MM-78 in dorsal (A) and ventral (B) views; virtual reconstruction of the upper teeth in occlusal view (C), and of the left upper teeth, from I3 to M1, in lingual (D) and buccal (E) views. C-E, upper teeth extracted virtually (including roots of left I1-I2), broken pieces stitched back together. For an easier visual representation, the shape of the dental arch approximates that of a modern river otter in occlusal view. Scale $=1 \mathrm{~cm}$ for A-B and C-E. Abbreviations can be found in the caption of figure 1 . Note that the roof of the tympanic bulla is displaced rostrally relative to the glenoid process (unnatural position). 
Magnetostratigraphy of the Middle Miocene continental sedimentary sequences of the Mae Moh Basin in northern Thailand: evidence for counterclockwise block rotation. Earth and Planetary Science Letters 204, 373-383. https://doi.org/10.1016/ S0012-821X(02)01002-6

Coster P., Benammi M., Chaimanee Y., Chavasseau O., Emonet E.-G. and Jaeger J.-J., 2010. A complete magnetic polarity stratigraphy of the Miocene continental deposits of Mae Moh basin, northern Thailand and a reassessment of the age of hominoid bearing localities in northern Thailand. Geological Society of America Bulletin 122, 1180-1191. https: //doi.org/10.1130/B26568.1

Ginsburg L., Ingavat R. and Tassy P., 1983. Siamogale thailandica, nouveau Mustelidae (Carnivora, Mammalia) néogène du Sud-Est asiatique. Bulletin de la Société Géologique de France 25(6), 953-956. https://doi.org/10.2113/gssgfbull.S7XXV.6.953

Grohé C., Chaimanee Y., Bonis L. de, Yamme C., Blondel C. and Jaeger J.-J., 2010. New data on Mustelidae (Carnivora) from Southeast Asia: Siamogale thailandica, a peculiar otterlike mustelid from the late Middle Miocene Mae Moh Basin, northern Thailand. Naturwissenschaften 97, 1003-1015. https: //doi.org/10.1007/s00114-010-0721-8

Grohé C., Bonis L. de, Chaimanee Y., Chavasseau O., Rugbumrung M., Yamee C., Suraprasit K., Gibert C., Surault J., Blondel C. and Jaeger J.-J., 2020. The late middle Miocene Mae Moh Basin of northern Thailand: the richest Neogene assemblage of Carnivora from Southeast Asia and a paleobiogeographic analysis of Miocene Asian carnivorans. American Museum Novitates. http://digitallibrary.amnh.org/handle/2246/7223

Lebrun R., 2014. ISE-MeshTools, a 3D interactive fossil reconstruction freeware. 12th Annual Meeting of EAVP, Torino, Italy.

Pilgrim G.E., 1932. The fossil Carnivora of India. Memoirs of the Geological Survey of India, Palaeontologia indica 18, $1-232$.

Tseng Z.J., Su D.F., Wang X., White S.C., Ji X., 2017. Feeding capability in the extinct giant Siamogale melilutra and comparative mandibular biomechanics of living Lutrinae. Scientific Reports 7, 15225. https://doi.org/10.1038/s41598-017-15391-9

Wang X., Grohé C., Su D.F., White S.C, Ji X., Kelley J., Jablonski N.G., Deng T., You Y. and Yang X. , 2018. A new otter of giant size, Siamogale melilutra sp. nov. (Lutrinae: Mustelidae: Carnivora), from the latest Miocene Shuitangba site in northeastern Yunnan, south-western China, and a total-evidence phylogeny of lutrines. Journal of Systematic Palaeontology 16(1), 39-65. https://doi.org/10.1080/14772019.2016.1267666

Werdelin L., 2003. Mio-Pliocene Carnivora from Lothagam, Kenya. In: Leakey M.G., Harris J.M. (editors), The dawn of Humanity in eastern Africa. Columbia University Press, New York, pp. 261-328. https://doi.org/10.7312/leak11870-013 